\title{
Author Correction: Rad52 prevents excessive replication fork reversal and protects from nascent strand degradation
}

Eva Malacaria ${ }^{1}$, Giusj Monia Pugliese ${ }^{1}$, Masayoshi Honda², Veronica Marabitti ${ }^{1}$, Francesca Antonella Aiello, Maria Spies ${ }^{2}$, Annapaola Franchitto ${ }^{1}$ \& Pietro Pichierri (iD 1,3

Correction to: Nature Communications https://doi.org/10.1038/s41467-019-09196-9, published online 29 March 2019.

The original version of this Article contained an error in Fig. 2. The immunofluorescence images in panel d were inadvertently replaced with duplicates of those in panel $c$ during final assembly of the figure. This has been corrected in the PDF and HTML versions of the Article.

Published online: 01 May 2019

(c) (1) Open Access This article is licensed under a Creative Commons Attribution 4.0 International License, which permits use, sharing, adaptation, distribution and reproduction in any medium or format, as long as you give appropriate credit to the original author(s) and the source, provide a link to the Creative Commons license, and indicate if changes were made. The images or other third party material in this article are included in the article's Creative Commons license, unless indicated otherwise in a credit line to the material. If material is not included in the article's Creative Commons license and your intended use is not permitted by statutory regulation or exceeds the permitted use, you will need to obtain permission directly from the copyright holder. To view a copy of this license, visit http://creativecommons.org/licenses/by/4.0/.

(c) The Author(s) 2019

\footnotetext{
${ }^{1}$ Mechanisms, Biomarkers and Models Unit, Department of Environment and Health, Istituto Superiore di Sanità, Viale Regina Elena 299,00161 Rome, Italy.

${ }^{2}$ Department of Biochemistry, Carver College of Medicine, University of lowa, 51 Newton Road 4-403 Bowen Science Building, lowa City, IA 52242, USA.

${ }^{3}$ Istituto Nazionale Biostrutture e Biosistemi, Viale delle Medaglie d'Oro, 305, 00136 Rome, Italy. These authors contributed equally: Giusj Monia Pugliese,

Masayoshi Honda. Correspondence and requests for materials should be addressed to P.P. (email: pietro.pichierri@iss.it)
} 